\title{
Nuclear Power Reactor Core Melt Accidents
}

\section{Current State of Knowledge}

\author{
Ahmed Bentaïb, Hervé Bonneville, Gérard Cénérino, \\ Bernard Clément, François Corenwinder, Michel Cranga, \\ Gérard Ducros, Florian Fichot, Didier Jacquemain, \\ Christophe Journeau, Vincent Koundy, Denis Leteinturier, \\ Daniel Magallon, Renaud Meignen, Frédérique Monroig, \\ Georges Nahas, Frédérique Pichereau, Emmanuel Raimond, \\ Jean-Marie Seiler, Bruno Tourniaire, Jean-Pierre Van-Dorsselaere
}

Didier Jacquemain, Coordinator

\section{sciences}


Cover illustration: Radiographic image of Phebus FP test devices and an artist's impression of the TMI-2 reactor core after fuel melt.

Printed in France

ISBN: 978-2-7598-1835-8

All rights reserved for all countries. This document may not be translated, adapted or reproduced by any means without permission. Pursuant to paragraphs 2 and 3 of Article 41 of the Act of 11 March 1957 only "copies or reproductions strictly reserved for the copyist's private use and not intended for collective use" are authorised. Regarding analyses and brief quotations intended as examples and illustrations, paragraph 1 of Article 40 of the same Act stipulates that "any representation, in whole or in part, made without the consent of the author or his/her successors or assignees is illicit." Such representation or reproduction, made by whatever means, therefore constitutes an infringement punishable under Articles 425 et seq. of the French Penal Code. 